\title{
Polarization Behavior of Zn-Ni-Fe Alloy Electrodeposition
}

\author{
Mary Mekheel YOUNAN* and Takeo OKI*
}

\section{Zn-Ni-Fe 合金析出の分極挙動}

\author{
マリー M. ユーナン*, 沖 猛 雄*
}

Key Words : Zn-Ni-Fe Alloy Plating, Electrodeposition, Polarization Curve, $\mathrm{Ni}^{2+} / \mathrm{Zn}^{2+}$ Molar Ratio

\section{Introduction}

Zn-Ni alloy coatings had usually dull and gray unattractive finish, and a brightener system had to be developed to obtain bright deposits ${ }^{1)}$. Recently, it is found that the bright $\mathrm{Zn}-\mathrm{Ni}-\mathrm{Fe}$ alloy electrodeposits were obtained in acidic chloride baths without any organic brightener ${ }^{2)}{ }^{3)}$. Also, this alloy exhibited better corrosion resistance and finer grain size in comparison with $\mathrm{Zn}-\mathrm{Ni}$ deposits $^{4}$.

This work is carried out to determine the effect of $\mathrm{Fe}$ codeposition on the polarization behavior of $\mathrm{Zn}-\mathrm{Ni}-\mathrm{Fe}$ alloy electroplating. Therefore, the cathodic polarization of binary $\mathrm{Zn}-\mathrm{Fe}, \mathrm{Ni}-\mathrm{Fe}$ and $\mathrm{Zn}-\mathrm{Ni}$ alloys deposition are also measured.

\section{Experimental}

$\mathrm{Zn}-\mathrm{Ni}-\mathrm{Fe}$ alloy electrodeposit was obtained at $40 \pm 2^{\circ} \mathrm{C}$ and $\mathrm{pH} 3$ using the following bath composition : $0.4 \mathrm{M} \mathrm{ZnCl}_{2}, 0.4 \mathrm{M} \mathrm{NiCl}_{2} \cdot 6 \mathrm{H}_{2} \mathrm{O}, 0.06 \mathrm{M}$ $\mathrm{FeCl}_{2} \cdot 4 \mathrm{H}_{2} \mathrm{O}, 2.5 \mathrm{M} \mathrm{NaCl}, 0.3 \mathrm{M} \mathrm{CH}_{3} \mathrm{COONa}$. $3 \mathrm{H}_{2} \mathrm{O}, 0.5 \mathrm{M} \mathrm{H}_{3} \mathrm{BO}_{3}$ and $0.5 \mathrm{~g} / \mathrm{L}$ dodecyl sodium sulfate. Also the electrodeposits of binary $\mathrm{Zn}$ $\mathrm{Fe}, \mathrm{Ni}-\mathrm{Fe}$ and $\mathrm{Zn}-\mathrm{Ni}$ alloys were obtained using the above plating parameters only with the required metal ions. All experiments were done in a glass beaker of $0.2 \mathrm{~L}$.

The cathodic polarization was measured using potentiostat at the scanning rate of $5 \mathrm{mV} / \mathrm{sec}$. The cathodic potential was measured against saturated calomel electrode (SCE). The counter electrode was platinum wire, while the working electrode was copper disk ( $1.5 \mathrm{~cm}$ diameter).

\section{Results and Discussion}

Fig. 1 shows the polarization curves of $\mathrm{Ni}$ $\mathrm{Fe}, \mathrm{Zn}-\mathrm{Fe}, \mathrm{Zn}-\mathrm{Ni}$ and $\mathrm{Zn}-\mathrm{Ni}-\mathrm{Fe}$ alloy deposition. The curves of $\mathrm{Ni}-\mathrm{Fe}$ and $\mathrm{Zn}-\mathrm{Fe}$ alloy deposition increased monotonously with cathodic potential

* Fac. of Eng., Nagoya Univ. (Furo-cho, Chikusa-ku, Nagoya-shi, Aichi 464-01, Japan)

名古屋大学 工学部

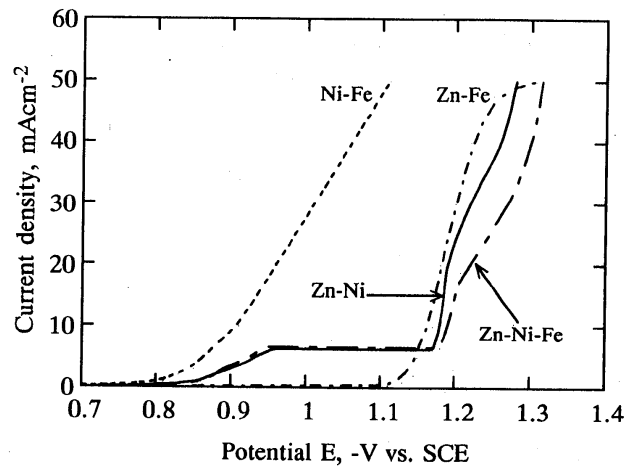

Fig. 1 Cathodic polarization curves of binary $\mathrm{Zn}-\mathrm{Fe}, \mathrm{Ni}-\mathrm{Fe}$ and $\mathrm{Zn}-\mathrm{Ni}$, and ternary $\mathrm{Zn}-\mathrm{Ni}-\mathrm{Fe}$ alloys electrodeposition.

in a similar manner as generally been observed in single metal deposition. On the contrary, there existed peculiar potential region in the curves of $\mathrm{Zn}-\mathrm{Ni}$ and $\mathrm{Zn}-\mathrm{Ni}-\mathrm{Fe}$ alloy deposition.

$\mathrm{Zn}-\mathrm{Ni}$ plating is one of the well-known anomalous type codeposition according to Brenner's definition ${ }^{5), 6)}$. The anomalous codeposition behavior of $\mathrm{Zn}-\mathrm{Ni}$ and $\mathrm{Zn}$-Co are attributed to the formation of zinc hydroxide film on the electrode surface, which suppresses the discharge of $\mathrm{Ni}$ or Co ions ${ }^{7), 8)}$. In the polarization curve of $\mathrm{Zn}-\mathrm{Ni}$ deposition in Fig. 1, there is a sharp potential increase at a certain current density, which is called transition critical current density from normal to anomalous region ${ }^{6)}$. And there is also a sudden current density jump at a certain potential. In these cathodic potential region, $\mathrm{Zn}-\mathrm{Ni}$ alloy deposition changes in phase from $\alpha$ to $\gamma$ solid solutions ${ }^{9}$.

The polarization behavior of $\mathrm{Zn}-\mathrm{Ni}-\mathrm{Fe}$ alloy deposition was similar to the $\mathrm{Zn}-\mathrm{Ni}$ plating. This reveals that the $\mathrm{Zn}-\mathrm{Ni}-\mathrm{Fe}$ alloy deposition may proceed by similar mechanisms to the ZnNi plating. However, the anomalous potential region of $\mathrm{Zn}-\mathrm{Ni}-\mathrm{Fe}$ alloys shifted to negative 


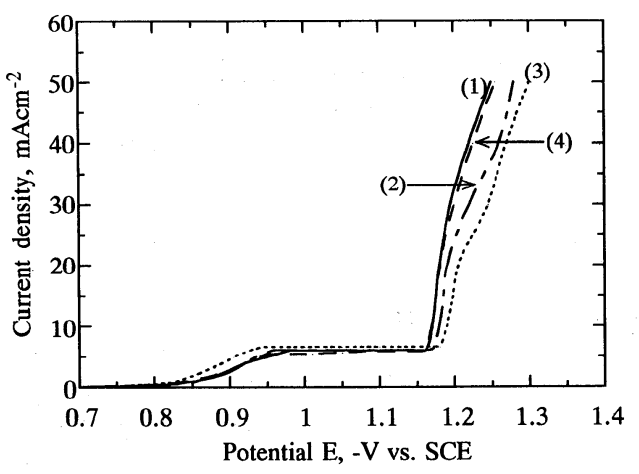

Fig. 2 Cathodic polarization curves of electrodeposited $\mathrm{Zn}$ $\mathrm{Ni}$ alloys from baths containing; (1) $0.4,0.3$, (2) $0.4,0.4$, (3) $0.4,0.5$ and (4) $0.5,0.4 \mathrm{M}$ of $\mathrm{Zn}^{2+}$ and $\mathrm{Ni}^{2+}$ respectively.

values in contrast to the $\mathrm{Zn}-\mathrm{Ni}$ plating.

Fig. 2 shows the effect of $\mathrm{Ni}^{2+} / \mathrm{Zn}^{2+}$ molar ratio on the polarization of $\mathrm{Zn}-\mathrm{Ni}$ deposition . With increase of $\mathrm{Ni}^{2+} / \mathrm{Zn}^{2+}$ molar ratio in the bath, the transition critical current density $\mathrm{Zn}-\mathrm{Ni}$ deposition increased slightly, and the anomalous potential region shifted to negative values. These may be attributed to the slight $\mathrm{pH}$ decrease on the electrode surface with increase of the molar ratio which causes the reduction of hydrogen overpotential. This consideration was confirmed by the results that the current efficiency for the alloy deposition decreased with increase of the molar ratio ${ }^{3)}$.

The polarization curves of ternary $\mathrm{Zn}-\mathrm{Ni}-\mathrm{Fe}$ alloy deposition from the bath of different $\mathrm{Ni}^{2+} /$ $\mathrm{Zn}^{2+}$ molar ratio with $0.06 \mathrm{M} \mathrm{FeCl}{ }_{2}$ are shown in Fig. 3. The transition critical current density was not affected by the addition of $\mathrm{FeCl}_{2}$. However, as mentioned previously, the anomalous potential regions shifted to negative values in contrast to those of $\mathrm{Zn}-\mathrm{Ni}$ deposition. These shifts became larger with increase of the molar ratio, and simultaneously, the iron contents in the alloy deposition increased ${ }^{3)}$. These may also be resulted from the reduction of hydrogen overpotential and the increase of charged $\mathrm{Fe}$ ions in the bath.

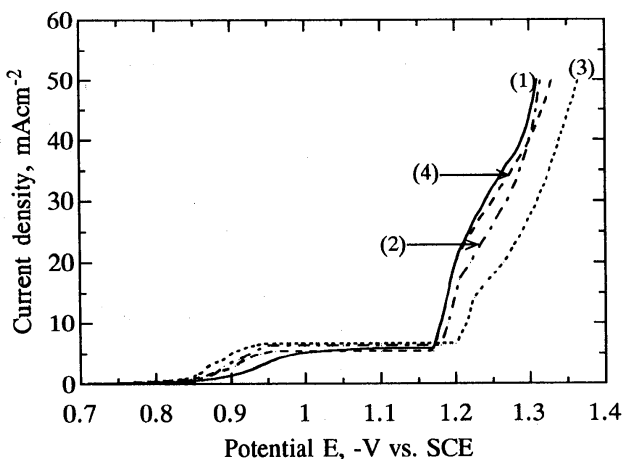

Fig. 3 Cathodic polarization curves of electrodeposited $\mathrm{Zn}$ $\mathrm{Ni}-\mathrm{Fe}$ alloys from baths containing $0.06 \mathrm{M}$ of $\mathrm{Fe}^{2+}$ and (1) $0.4,0.3$, (2) $0.4,0.4$, (3) $0.4,0.5$ and (4) 0.5 , $0.4 \mathrm{M}$ of $\mathrm{Zn}^{2+}$ and $\mathrm{Ni}^{2+}$ respectively.

\section{Conclusion}

The electroplating of ternary $\mathrm{Zn}-\mathrm{Ni}-\mathrm{Fe}$ alloy exhibited the anomalous type codeposition. The transition from normal to anomalous codeposition was observed at low critical current densities. The transition critical current density was not affected by addition of $0.06 \mathrm{M} \mathrm{FeCl}{ }_{2}$ and just as it was in $\mathrm{Zn}-\mathrm{Ni}$ deposition. The anomalous potential region of $\mathrm{Zn}-\mathrm{Ni}-\mathrm{Fe}$ alloy was shifted to negative values in contrast to these of $\mathrm{Zn}-\mathrm{Ni}$ alloy.

(Received December 26, 1995 ; Accepted February 28, 1996)

\section{References}

1) J. A. Dini and H. R. Johnson ; Met. Finish., 77, 53 (1979)

2) M. M. Younan, T. Oki, M. A. Arafa and A. T. ElMallah ; Under press in the Journal of Metal Finishing

3) M. M. Younan and T. Oki ; Under press in the Journal of Applied Electrochemistry

4) T. Oki and M. M. Younan; Under press in the Journal of Galvanotechnik

5 ) A. Brenner ; Electrodeposition of Alloys, Vol. 1 (Academic Press, New York and London, 1963)

6 ) D. E. Hall ; Plat. Surf. Finish., 71, 59 (1983)

7) H. Fukushima, T. Akiyama, K. Higashi, R. Kammel and M. Karimkhani ; Metall., 42, 242 (1988)

8 ) K. Higashi, H. Fukushima, T. Urakawa, T. Adaniya and K. Matsudo ; J. Electrochem. Soc., 128, 2081 (1981)

9) Benjamin Lustman ; Trans. Electrochem. Soc., 84, 363 (1943) 